Review Article

\title{
Soybean genetic transformation: A valuable tool for the functional study of genes and the production of agronomically improved plants
}

\author{
Milena Schenkel Homrich ${ }^{1 *}$, Beatriz Wiebke-Strohm ${ }^{1,2 *}$, Ricardo Luís Mayer Weber ${ }^{1}$ \\ and Maria Helena Bodanese-Zanettini ${ }^{1}$ \\ ${ }^{1}$ Programa de Pós-Graduação em Genética e Biologia Molecular, Departamento de Genética, \\ Instituto de Biociências, Universidade Federal do Rio Grande do Sul, Porto Alegre, RS, Brazil. \\ ${ }^{2}$ Centro de Biotecnologia, Instituto de Biociências, Universidade Federal do Rio Grande do Sul, \\ Porto Alegre, RS, Brazil.
}

\begin{abstract}
Transgenic plants represent an invaluable tool for molecular, genetic, biochemical and physiological studies by gene overexpression or silencing, transposon-based mutagenesis, protein sub-cellular localization and/or promoter characterization as well as a breakthrough for breeding programs, allowing the production of novel and genetically diverse genotypes. However, the stable transformation of soybean cannot yet be considered to be routine because it depends on the ability to combine efficient transformation and regeneration techniques. Two methods have been used with relative success to produce completely and stably transformed plants: particle bombardment and the Agrobacterium tumefaciens system. In addition, transformation by Agrobacterium rhizogenes has been used as a powerful tool for functional studies. Most available information on gene function is based on heterologous expression systems. However, as the activity of many promoters or proteins frequently depends on specific interactions that only occur in homologous backgrounds, a final confirmation based on a homologous expression system is desirable. With respect to soybean biotech improvement, transgenic lines with agronomical, nutritional and pharmaceutical traits have been obtained, including herbicide-tolerant soybeans, which represented the principal biotech crop in 2011, occupying $47 \%$ of the global biotech area.
\end{abstract}

Keywords: transgenic plants, particle bombardment, Agrobacterium systems, functional analysis, genetic improvement.

\section{Economic Importance of Soybean}

The economic importance of soybeans worldwide as a source of oil and meal for human and animal consumption as well as for industrial uses, such as biofuel production, has made this crop a target for genetic improvement. Conventional soybean breeding programs are frequently handicapped by the restrictive variability of its germplasm. Plant genetic transformation provides an attractive advancement for soybean breeding programs, allowing the production of novel and genetically diverse plant materials. Transgenic plants also represent a priceless tool for molecular, genetic, biochemical and physiological studies by gene overexpression or silencing, transposon-based mutagenesis, protein sub-cellular localization and/or promoter characterization.

Send correspondence to Maria Helena Bodanese-Zanettini. Departamento de Genética, Instituto de Biociências, Universidade Federal do Rio Grande do Sul, Caixa Postal 15053, 91501-970 Porto Alegre, RS, Brazil. E-mail: maria.zanettini@ufrgs.br.

${ }^{*}$ These authors contributed equally to this work.
Biotech soybeans are the principal biotech crop, occupying $47 \%$ of 160 million hectares of the global biotech area in 2011. Brazil is currently the second largest producer of soybeans in the world after the USA and is expected to become the first in the future (James, 2011). A study by Celeres has estimated that approximately $85 \%$ of the soybean growing area was planted with biotech seeds during the $2011 / 2012$ season. Five biotech soybean products have already been approved for commercialization by the National Technical Commission on Biosecurity in Brazil. Considering the economic relevance of the soybean for our country and the continuing challenge to overcome biotic and abiotic stresses, biotech products can have a significant impact on accelerating Brazilian breeding programs.

\section{Soybean Transformation Procedures}

Soybean transformation was first reported in 1988 (Christou et al., 1988; Hinchee et al., 1988). Even after more than two decades, the stable transformation of soybeans cannot yet be considered to be routine because it depends on the ability to combine efficient transformation 
and regeneration techniques. Two methods have been used with relatively greater success to produce completely and stably transformed plants: particle bombardment and the Agrobacterium tumefaciens system. Both systems are equally important in basic science and agricultural applications. In addition, the transformation of soybean roots by Agrobacterium rhizogenes has been used as a powerful tool for functional studies.

According to Somers et al. (2003), there are three main requirements to establish an efficient transformation system: (a) a source of totipotent cells that serve as recipients of the delivered DNA, (b) a means of delivering DNA into the target cells, and (c) a system for selecting or identifying the transformed cells. The main advances in soybean transformation protocols are reported below.

\section{Particle bombardment and target tissues}

Genetic transformation by particle bombardment, also called particle or projectile acceleration, biolistics or biobalistics, consists of the introduction of DNA into intact cells and tissues by accelerated microparticles driven at high speeds (Sanford, 1988). Accelerated particles are able to cross the cell wall and the cell and nuclear membranes. In the nucleus, exogenous DNA fragments are liberated and may be integrated into chromosomal DNA through the processes of illegitimate or homologous recombination, which depend exclusively on cellular components (Sanford, 1990; Kohli et al., 2003).

The main advantage of particle bombardment lies in the possibility of transfering genes to any cell or tissue type independently of genotype and without having to consider the compatibility between the host and bacterium, as required by the Agrobacterium system. Particle bombardment is also quicker and easier to use. However, this technique introduces multiple DNA copies that may be fragmented or recombined (Hadi et al., 1996).

Since 1988 when the first transgenic soybean plant was generated (Christou et al., 1988), many reports describing soybean transformation by particle bombardment using meristems as the target tissue have been published (McCabe et al., 1988; Christou et al., 1989; Christou and McCabe, 1992; Aragão et al., 2000; Vianna et al., 2011). Importantly, the original apical meristem in soybean is composed of multiple cell layers (L1, L2 and L3) (Christou et al., 1990; Christou and McCabe, 1992), and all three layers are involved in the production of the whole shoot, with L1 being responsible for the epidermis and L 2 and L3 being responsible for the production of the more internal tissues (Sussex, 1989). This composition explains why plants resulting from the transformation of shoot meristems are often chimeric (Sato et al., 1993), and thus the acquisition of transgenic progeny depends on the transformation of the internal cell layer. A significant increase in the recovery of fertile transgenic soybean plants was reported by Rech et al. (2008), who combined the bombardment of embryo- genic axes, multiple shoot induction and a selection system based on the imazapyr herbicide.

Somatic embryogenesis (SE) in soybean was first reported by Christianson et al. (1983) and provides an alternative system to proliferate and regenerate tissues in vitro. SE consists of the development of embryos from microspores or somatic tissues in a process that generates a plant without involving gamete fusion (Williams and Maheswaran, 1986).

Initially, the transformation of primary somatic embryos originated chimeric plants (Parrott et al., 1989) due to their multicellular nature (Finer, 1988). The latter author showed that secondary somatic embryos could be proliferated directly from the apical or terminal portions of the older primary somatic embryos and that secondary embryogenesis could be achieved by keeping the tissue in a medium rich in 2,4-dichlorophenoxyacetic acid (2,4-D). Furthermore, Sato et al. (1993) proved that the proliferation of secondary somatic embryos occurred from single cells of primary or secondary embryos. The unicellular origin of secondary embryos makes this tissue ideal as the main target for genetic transformation because the risk of generating chimeras is eliminated (Sato et al., 1993).

Somatic embryos can be regenerated and proliferated on semi-solid media (Parrott et al., 1988; Finer, 1988) or in liquid suspension culture media (Finer and Nagasawa, 1988). Several studies of soybean transformation via particle bombardment using embryogenic tissues have been published (Finer and McMullen, 1991; Finer et al., 1992; Stewart Jr et al., 1996; Droste et al., 2002; Homrich et al., 2008a; Wu et al., 2008; Li et al., 2009; Hernandez-Garcia et al., 2009; Xing et al., 2010).

The use of 2,4-D and long duration culture tends to produce genetic and epigenetic variations in many plant species (Larkin and Scowcroft, 1981). In soybean, a direct relationship between somatic embryogenesis and somaclonal variation has not been demonstrated thus far. However, a cytological examination of embryogenic tissues and the recovered plants revealed various chromosomal aberrations, with the soybean genotypes differing in their susceptibility to tissue culture-induced chromosomal instability (Singh et al., 1998). In addition, plants regenerated from old embryogenic cultures showed problems with sterility (Hadi et al., 1996) and a range of phenotypic abnormalities (Singh et al., 1998). Therefore, the establishment and transformation of young $(<1$ year old) embryogenic cultures are imperative (Trick et al., 1997a).

Particle bombardment can be achieved through highor low-helium pressure gene guns, enabling the penetration of the target tissue to be controlled very accurately so that the majority of the particles carrying the DNA can be directed to a specific cell layer. This feature is extremely important because different explants may require different acceleration conditions for optimum particle penetration (Christou et al., 1990). Meristems (composed of multiple 
cell layers) require the employment of high-pressure equipment to reach the inner layers. In contrast, secondary somatic embryos (originated from single epidermal cells) require shallow penetration, which is achieved by lowpressure bombardment (Sato et al., 1993). Finer et al. (1992) developed a particle accelerator called the Particle Inflow Gun (PIG), which was successfully applied in soybean somatic embryo transformation (Droste et al., 2002; Homrich et al., 2008a, Hernandez-Garcia et al., 2009).

\section{Agrobacterium system}

Agrobacterium is a soil-borne Gram-negative phytopathogenic bacterium that naturally infects different plants (DeCleene and DeLey, 1976). These phytopathogens cause a variety of neoplasms, including crown gall disease ( $A$. tumefaciens and $A$. vitis), hairy root disease ( $A$. rhizogenes), and cane gall disease (A. rubi) on numerous plant species (Gelvin, 2010b). The origin of these sicknesses is interkingdom horizontal gene transfer. When virulent strains of Agrobacterium infect plant cells, they transfer one or more segments of DNA (transferred DNA or T-DNA) from the Ti (Tumor inducing) or Ri (Root inducing) plasmids into the host plant cells (Gelvin, 2003). This gene transfer process was recently reviewed (Gelvin, 2010a,b; Pitzschke and Hirt, 2010).

In the last 30 years, disarmed (non-tumorigenic) Agrobacterium strains have provided a means to produce genetically modified plants. To obtain engineered (binary) vectors derived from $\mathrm{Ti}$ or Ri plasmids, genes present in the T-DNA region are replaced by foreign DNA (Gelvin, 2010b). The advantages of Agrobacterium-mediated gene transfer over particle bombardment include the possibility of transferring relatively large segments of DNA, a lower number of transgene copies integrated into the plant genome, rare transgene rearrangement, a lower frequency of genomic DNA interspersion and reduced abnormal transgene expression (Gelvin, 2003; Kohli et al., 2003). Moreover, this system involves a low operating cost and simple transformation protocols (Brasileiro and Lacorte, 2000). However, plants differ greatly in their susceptibility to Agrobacterium-mediated transformation. These differences occur among species, cultivars or tissues (Droste et al., 1994; Gelvin, 2010b; Wiebke-Strohm et al., 2011). According our experience, this transformation system usually results in lower transformation rates compared with particle bombardment (Wiebke-Strohm et al., 2012).

\section{Agrobacterium tumefaciens and target tissues}

Agrobacterium was initially considered to be nonpathogenic to soybean (DeCleene and DeLey, 1976). However, later studies showed soybean was susceptible to this bacterium (Pedersen et al., 1983; Droste et al., 1994; Mauro et al., 1995). The addition of acetosyringone during bacterial infection, selection of the most appropriate $A$. tumefaciens strain and soybean cultivar, and development of super-virulent plasmids have contributed to the increased efficiency of soybean transformation (reviewed by Somers et al., 2003).

Recovery of the first transgenic soybean plants using A. tumefaciens-mediated transformation was reported by Hinchee et al. (1988), using cotyledonary nodes as the target tissue. Subsequently, advances in transformation techniques were achieved, and several research teams have reported the generation of transgenic plants using different target tissues, such as cotyledonary nodes (Paz et al., 2004; Liu et al., 2008), hypocotyls (Aragão et al., 2000; Wang and $\mathrm{Xu}, 2008$ ), half-seeds (Paz et al., 2006), organogenic callus (Hong et al., 2007), and immature zygotic cotyledons (Parrott et al., 1989; Yan et al., 2000; Ko et al., 2003, 2004).

Although secondary somatic embryos remain the major target for soybean transformation via particle bombardment, the transformation of these tissues via A. tumefaciens has been proven to be challenging. Instead of the conventional A. tumefaciens-mediated transformation system, alternative methods have been proposed for this target tissue: the "Sonication-Assisted Agrobacterium-mediated Transformation (SAAT)" (Trick et al., 1997b, Trick and Finer, 1998) and the "combined DNA-free particle bombardment and Agrobacterium system (bombardment/Agrobacterium system)" (Droste et al., 2000; Wiebke et al., 2006, Wiebke-Strohm et al., 2011). The difference between these methods lies in the technique used to induce tissue wounding to provide an entry point for the bacteria: SAAT uses sonication, and the other system relies upon bombardment. Unfortunately, both systems are time-consuming and laborious and depend on the availability of specific equipment for routine application.

Despite these advances, only a few viable transgenic lines have been generated from the above experiments, showing that more appropriate and effective methods need to be developed to improve the efficiency of soybean transformation via $A$. tumefaciens.

\section{Agrobacterium rhizogenes}

The $A$. rhizogenes-mediated transformation leads to the development of the hairy-roots phenotype, consisting of roots that grow plagiotropically and rapidly and are highly branched in the absence of exogenous plant growth regulators (Collier et al., 2005). A. rhizogenes can co-transfer T-DNAs from the Ri plasmid and from a binary vector containing the gene of interest into the plant genome (Christey, 2001; Broothaerts et al., 2005). Hairy-roots can be clonally propagated in culture medium (Chabaud et al., 2006). In addition, "composite plants", i.e., plants with wild-type shoots and transgenic roots, can be obtained (Collier et al., 2005). Each transgenic hairy-root represents an independent transformation event, and high numbers of transformants can be obtained and analyzed (Kereszt et al., 2007). The major advantage is a relatively short period (approxi- 
mately 6-8 weeks) needed to screen potential genes and promoters in the stably transformed tissues (Cho et al., 2000).

A. rhizogenes-mediated transformation has become a powerful tool for gene functional and root biology studies due to its quick and simple methodology (Kereszt et al., 2007; Cao et al., 2009). In soybeans, the method has been used to characterize promoters (Hernandez-Garcia et al., 2010), the propagation of nematodes (Cho et al., 2000), symbiotic interactions (Hayashi et al., 2008), pathogenic interactions (Lozovaya et al., 2004; Li et al., 2010), and gene silencing via RNAi (Subramanian et al., 2005).

Unlike other plants species, there are no reports to date on successful plant regeneration from soybean hairyroots. However, Olhoft et al. (2007) reported the recovery of complete and stable soybean transgenic plants from primary-node explants infected by a disarmed $A$. rhizogenes strain.

\section{Selection System}

Regardless of the gene delivery system used, the process of producing transgenic plants often requires an effective means for identifying and selecting transgenic cells and tissues. Selectable marker genes are able to lend resistance or tolerance to antibiotics or herbicides, allowing the selection of the transgenic material.

The hygromycin antibiotic has been successfully used as a selection agent and become the standard for the selection of soybean transgenic tissues, especially embryogenic tissues (Trick et al., 1997b; Trick and Finer, 1998; Droste et al., 2000; Droste et al., 2002; Wiebke et al., 2006; Homrich et al., 2008a; Hernandez-Garcia et al., 2009; Li et al., 2009; Wiebke-Strohm et al., 2011; Wiebke-Strohm et al., 2012) and cotyledonary node cells (Olhoft et al., 2003). Olhoft et al. (2003) demonstrated that hygromycin reduces both the number of non-transformed escapes and the time in culture.

Some studies have reported the use of different herbicides for selecting soybean transgenic tissues. The phosphinothricin acetyltransferase (PAT) proteins, which are encoded by the bar coding sequence from Streptomyces hygroscopicus or the pat coding sequence from Streptomyces viridochromogenes, are present in glufosinate-ammonium-tolerant plant varieties of various crops, such as corn, cotton, rice, oilseed rape, and soybean. The soybean transformation efficiency was maximized by using optimized levels of glufosinate during the selection of transgenic shoots recovered from cotyledonary nodes (Zhang et al., 1999; Zeng et al., 2004). Rech et al. (2008) developed a novel system to select transgenic meristematic cells from embryogenic axes after the introduction of an Arabidopsis mutant gene (csrl-2) to achieve resistance to imidazolinone herbicides. The success of this agent in the selection of transgenic embryogenic axes is attributed to its ability to translocate and be concentrated in the apical meristematic region of the embryogenic axes. Preliminary results in our lab showed that this marker/agent can also efficiently select transgenic somatic embryos (unpublished results). Rao et al. (2009) successfully developed a system to select somatic embryos using the E. coli dapA gene, which confers resistance to glufosinate, glyphosate, S-(2 aminoethyl)-L-cysteine and imidazolinones.

\section{Functional Characterization of Soybean Genes}

Considerable progress has been made in developing genomic resources for soybean, the model plant for legume studies (Gepts et al., 2005), including sequencing its genome (Schmutz et al., 2010). A large number of soybean genes have been identified, most with unknown function. Therefore, a major research priority in the post-genome sequencing era is determining the function of these genes, especially those involved in agronomic performance (Wesley et al., 2001; Kokkirala et al., 2010). The integration of genetic and genomic data from multiple legumes and other plant species provides support for soybean genome annotation and comparative functional genomics (Tran and Mochida, 2010). Although annotation may suggest a gene function, confirmation through biochemical or genetic studies is necessary.

The primary tool for dissecting a genetic pathway is the screen for the loss of gene function, disrupting the target pathway. However, the limitations of this method are the following: (i) genes that act redundantly are rarely identified, (ii) inferring function is difficult when genes act during multiple stages of the life cycle, and (iii) the loss of function of important genes is lethal (Weigel et al., 2000; Zhang, 2003).

Modern biotechnology has enabled the elucidation of gene function through the systematic modification of gene expression followed by quantitative and qualitative analyses of the gene expression products. The modulation of gene expression can be achieved by the integration of foreign DNA sequences in the plant genome, leading to either overexpression or gene silencing. Gene silencing is currently achieved through interference RNA (RNAi), a process of sequence-specific, post-transcriptional gene silencing initiated by double-stranded RNA that is homologous in sequence to the target gene. Overexpression and silencing are complementary strategies to functionally characterize genes. The main advantage of overexpression is the low effect of other genes with functional redundancy (Zhang, 2003).

An alternative route to down-regulate gene expression is to couple T-DNA regions with transposon elements. The T-DNA integration into the plant genome can disrupt the coding region of a gene, resulting in gene inactivation. Because T-DNA insertions tend to reside in transcriptionally active regions, subsequent movement of the transposon throughout the genome would provide launching sites for further mutagenesis upon the activation of 
transposition (Mathieu et al., 2009). In the long-term, the building of a transposon-mutant collection may provide an important resource for functional genomic studies.

Transient alterations in gene expression can also be generated by virus-induced gene silencing (VIGS) (Baulcombe, 1999; Burton et al., 2000), a method that exploits an RNA-mediated anti-viral defense mechanism. The advantage of VIGS is that entire cDNA libraries can be cloned into the viral vector instead of individual genes. VIGS can also be used to target genes that, when stably mutated or silenced, cause lethal effects on plant development (BurchSmith et al., 2004). However, VIGS-mediated phenotypes are transient, and appropriate viral vectors that can infect and alter gene expression in desired species need to be developed (Tadege et al., 2005).

Methods for the subcellular localization of proteins provide an important tool to determine their functions (Kokkirala et al., 2010). The fusion of a gene of interest to a reporter gene or tag is a convenient and powerful method for protein subcellular localization (Nakagawa et al., 2007; Kokkirala et al., 2010). A large number of vectors are available for this use (Karimi et al., 2002; Nakagawa et al., 2007). Techniques for the subcellular localization of proteins are also effective in the detailed analysis of gene networks, including colocalization, complex formation, gene product interactions and protein relocation (Nakagawa et al., 2007).

The characterization of new promoters represents another relevant topic of research to provide new tools for transgene manipulation. The constitutive cauliflower mosaic virus 35S RNA promoter (CaMV 35S) is the most widely used in plant biotechnology (Odell et al., 1985). However, the promoter derived from the soybean polyubiquitin (Gmubi) gene is able to induce constitutive gene expression at levels up to five-fold higher than the traditional CaMV 35S promoter (Chiera et al., 2007; Hernandez-Garcia et al., 2009). The promoter of the GmHSP90L gene, which encodes a heat shock protein, is four-fold more potent than the CaMV 35S promoter (Chiera et al., 2007). Thus, both are alternative promoters for soybean transformation.

In some cases, a high expression level of a recombinant protein can be detrimental to the plant due to toxicity. In other cases, the protein can be unnecessary in certain tissues and/or developmental stages. Therefore, regulating transgene expression by tissue-specific or inducible promoters would be advisable (Preiszner et al., 2001; Qinggele et al., 2007). Inducible promoters are activated by biotic or abiotic factors, and they should prevent gene expression during steps that interfere in the growth, regeneration or reproduction of transgenic plants (Boetti et al., 1999). Tissue-specific promoters have the potential to direct gene expression to specific plant tissues or organs where the accumulation of recombinant proteins is needed (Ma et al., 2003).
Most available information on genetic modification is based on heterologous expression systems (Chen et al., 2007; Xue and Zhang, 2007; Zhang et al., 2009b; Zhou et al., 2010). Studies with model plants produce results faster and have been well accepted by the scientific community. Sometimes the gene function is the same in both homologous and heterologous backgrounds (Mazarei et al., 2007). Frequently, however, the activity of many promoters or proteins depends on specific interactions that are only found in homologous backgrounds. In these cases, a final confirmation of gene/promoter function in a homologous expression system is desirable (Krajewska, 2009; Hernandez-Garcia et al., 2010). A relatively large number of reports on functional studies in the soybean were performed in heterologous systems. However, there are few reports in homologous systems (see Table 1).

\section{Soybean Transformation in Agriculture}

The first generation biotech crops offered a significant increase in yield and production by protecting crops from losses caused by pests, weeds, and diseases. The main advantages of biotech products available in the market include the following: (i) existence of farmer demand for techniques facilitating their work; (ii) reductions in production losses; and (iii) reduced amounts of chemicals used on crops or the use of less toxic products (Job, 2002; James, 2011). Based on the genesis of biotech crop commercialization from 1996 to 2011, herbicide tolerance and insect resistance have consistently been the dominant traits of interest. Herbicide-tolerant soybean remains the dominant crop in 2011, occupying $47 \%$ of the global biotech area (James, 2011). Brazil recently approved the first stacked soybean with insect resistance and herbicide tolerance for commercialization (www.ctnbio.gov.br).

Many countries and companies are now fast-tracking the development of new soybean biotech crops featuring (i) superior nutritional traits, (ii) improved yield by enhanced tolerance to stresses, (iii) the capability to produce therapeutic products and vi) the capability of being used as biomass for biofuels (Job, 2002; McGloughlin, 2008).

\section{Herbicide-tolerant soybean plants}

Roundup Ready (RR) crops (registered trademarks of Monsanto Technology LLC) are tolerant to the herbicide glyphosate (N-[phosphonomethyl] glycine). Glyphosate tolerance was obtained through the expression of the 5enol-pyruvyl-shikimate-3-phosphate synthase (epsps) gene from Agrobacterium spp. strain CP4. The introduced glyphosate-tolerant EPSPS enzyme meets the plant's need for aromatic amino acids and other metabolites that are essential for plant development and growth in the presence of glyphosate (Padgette et al., 1995). Extensive research efforts have led to the development of a second-generation glyphosate-tolerant soybean product. Although both transgenic events produce identical CP4 EPSPS proteins, the 
Table 1 - Functional studies of soybean genes by overexpression, silencing, transposon-based mutagenesis, protein sub-cellular localization and/or promoter characterization.

\begin{tabular}{|c|c|c|}
\hline References & Approach & Description \\
\hline Nunes et al. (2006) & Gene silencing RNAi & $\begin{array}{l}\text { Correlation between myo-inositol-1-phosphate ( } G m \text { MIPS1) gene expression } \\
\text { and seed development }\end{array}$ \\
\hline Lee et al. (2005) & Gene silencing RNAi & $\begin{array}{l}\text { The role of the thioredoxin gene in nodule development and the mainte- } \\
\text { nance of the symbiotic state }\end{array}$ \\
\hline Govindarajulu et al. (2009) & Gene silencing RNAi & The role of GS52 ecto-apyrase gene during the nodulation process \\
\hline Zhang et al. (2009a) & Gene silencing VIGS & $\begin{array}{l}\text { Transient silencing of the actin gene resulting in a reduced number of soy- } \\
\text { bean mosaic virus (SMV) infection foci }\end{array}$ \\
\hline Pandey et al. (2011) & Gene silencing VIGS & $\begin{array}{l}\text { Screening of } 140 \text { genes for their ability to compromise resistance to } \\
\text { Phakopsora pachyrhizi }\end{array}$ \\
\hline Mathieu et al. (2009) & $\begin{array}{l}\text { Gene silencing Transposon-based } \\
\text { mutagenesis }\end{array}$ & $\begin{array}{l}\text { Dissociation (Ds) transposon of maize: an effective tool for the mutagenesis } \\
\text { of soybean }\end{array}$ \\
\hline $\begin{array}{l}\text { Kim et al. (2001); Yanxiang et al. } \\
\text { (2006); Wu et al. (2008); Zhang et } \\
\text { al. (2009b); Zhou et al. (2010) }\end{array}$ & Overexpression & Examples of soybean gene overexpression in a heterologous background \\
\hline Mazarei et al. (2007) & Overexpression & $\begin{array}{l}\text { Characterization of the soybean ethylene-responsive element-binding pro- } \\
\text { tein }(G m \text { EREBP1) encoding gene as a transcription factor, which induces } \\
\text { the expression of defense-related genes }\end{array}$ \\
\hline Chen et al. (2009) & Overexpression & $\begin{array}{l}\text { GmDREB3 overexpression increasing the tolerance to cold, drought and } \\
\text { salt }\end{array}$ \\
\hline Hur et al. (2009) & Overexpression & $\begin{array}{l}\text { The role of the soybean aldo/keto reductase } 1 \text { gene }(G m A K R 1) \text { in the regu- } \\
\text { lation of nodule formation }\end{array}$ \\
\hline $\begin{array}{l}\text { Dhaubhadel et al. (2008); Chung et } \\
\text { al. (2009); Yang et al. (2010); Yi et } \\
\text { al. (2010); Li and Dhaubhadel } \\
\text { (2011); Mazarei et al. (2007); } \\
\text { Huang et al. (2009) }\end{array}$ & Subcellular localization & $\begin{array}{l}\text { Examples of the subcellular localization of soybean gene products using } \\
\text { heterologous systems }\end{array}$ \\
\hline Preiszner et al. (2001) & Promoter characterization & Characterization of the soybean $A d h$ gene promoter in transgenic hairy roots \\
\hline Subramanian et al. (2004) & Promoter characterization & $\begin{array}{l}\text { Study of soybean isoflavone synthase promoters in response to the plant/ni- } \\
\text { trogen-fixing bacteria interaction }\end{array}$ \\
\hline Hernandez-Garcia et al. (2009) & Promoter characterization & $\begin{array}{l}\text { Characterization of the soybean polyubiquitin gene promoter }(\mathrm{Gm} \mathrm{Ubi}) \text { in } \\
\text { transgenic soybean plants }\end{array}$ \\
\hline Chen et al. (2009) & Promoter characterization & Characterization of the $G m$ DREB3 promoter in response to cold stress \\
\hline Chiera et al. (2007) & Promoter characterization & Characterization of a soybean heat shock protein 90-like ( $\mathrm{GmHSP}$ H0L) \\
\hline Qinggele et al. (2007) & Promoter characterization & $\begin{array}{l}\text { Isolation and analysis of BCSP } 666 \text {, a promoter fragment with seed-specific } \\
\text { activity }\end{array}$ \\
\hline Cho et al. (1995) & Promoter characterization & $\begin{array}{l}\text { Construction of expression cassettes containing regions of the soybean } \\
\text { lectin gene promoter useful for driving foreign gene expression to modify } \\
\text { embryo-specific traits }\end{array}$ \\
\hline
\end{tabular}

second-generation RR soybean has a yield advantage compared with the first in the same elite genetic background (Lundry et al., 2008; Levy-Booth et al., 2009).

Recently, the National Technical Commission on Biosecurity in Brazil approved the commercial release of a new class of genetically modified soybeans: the Soybean CV127 ("Cultivance"), which is tolerant to herbicides of the imidazolinone chemical class. The CV127 soybean has been genetically modified by researchers from Embrapa (The Brazilian Agricultural Research Corporation) to express an altered csrl-2 gene from Arabidopsis thaliana, supplied by the German company BASF (Rech et al., 2008). The AtAHASL protein encoded by csr $1-2$ is structurally and functionally identical to the native AtAHASL, except for a serine to asparagine substitution at residue 653 $(\mathrm{S} 653 \mathrm{~N})$ that results in tolerance to imidazolinone herbicides (Sathasivan et al., 1991).

\section{Insect-resistant soybean plants}

Bacillus thuringiensis $(B t)$ is an entomopathogenic bacterium widely used as a biopesticide to control pest insects. B. thuringiensis produces proteins ( $\delta$-endotoxins) that are stored around spores, forming crystals (Peferöen, 1997) that exert specific toxic activity against lepidopteran, dipteran, and coleopteran larvae (Hongyu et al., 2000).

The transgenic expression of $\mathrm{Bt}$ proteins is reportedly very effective for controlling insect pests in several major crop plants, especially corn and cotton (James, 2011). A 
stacked soybean $(\mathrm{Bt} / \mathrm{RR})$ was recently approved for commercialization in Brazil, and other soybean $\mathrm{Bt}$ lines have been developed. Parrott et al. (1994) reported that the expression of a native crylAb gene prevented Anticarsia gemmatalis larval feeding and growth. A transgenic line expressing high levels of a synthetic $c r y l A c$ gene caused complete $A$. gemmatalis larval mortality and significantly reduced Pseudoplusia includens and Helicoverpa zea larval survival and feeding in laboratory bioassays (Stewart Jr et al., 1996) and in artificially infested field cages (Walker et al., 2000). Transgenic soybean lines expressing a synthetic cry $1 A$ gene exhibited a virtually complete efficacy against several lepidopteran pests in screenhouse and field trials (Macrae et al., 2005; McPherson and Macrae, 2009). Transgenic soybean lines expressing a cry $1 \mathrm{~A}$ synthetic gene with a high degree of resistance against the lepidopteran pests Pseudoplusia includes, Helicoverpa zea and Anticarsia gemmatalis was reported by Miklos et al. (2007). Similarly, Homrich et al. (2008a) described the development of a transgenic soybean expressing a synthetic cryl Ac gene. In vitro and in vivo bioassays indicated that the transgenic plants were highly toxic to A. gemmatalis. The results from an additional study showed that $c r y l \mathrm{Ac}$ transgene did not affect the agronomic performance and yield (Homrich et al., 2008b).

\section{Other transgenic soybean lines with agronomic, nutritional and industrial interest}

Soybean growth, productivity and seed quality are affected by a wide range of abiotic and biotic stresses. Drought is considered the main abiotic stress, reducing soybean yield by approximately $40 \%$ and affecting all stages of plant growth and development (Manavalan et al., 2009).With regards to biotic stresses, Asian soybean rust (ASR), caused by the fungus Phakopsora pachyrhizi Sydow and Sydow, is one of the most severe diseases in soybean culture, resulting in 10-90\% crop losses in different regions (Yorinori et al., 2005).

Genetic engineering using genes encoding components of stress-related metabolic pathways has shown the potential to enhance drought resistance in the soybean. Transgenic soybean plants overexpressing the Arabidopsis $\Delta$ 1-pyrroline-5-carboxylate synthase (P5CR) gene showed greater tolerance to drought and heat stresses due to an increased free proline level (De Ronde et al., 2004a,b; Kocsy et al., 2005). Alternatively, tolerance to stresses could be achieved by modulating the expression of stress-induced transcription factors (TF), which in turn would regulate the expression of a large number of relevant downstream genes (Agarwal et al., 2006). Different TFs related to stress have been identified. DREBs belong to the ethylene-responsive factors (ERF) family of TFs and play a crucial role in providing tolerance to multiple stresses. A drought-sensitive BR16 soybean cultivar was transformed with the AtDREB1A gene under the control of a drought-inducible promoter (rd29A) from A. thaliana. The modified plants had more chlorophyll, higher stomatal conductance, and higher photosynthetic and transpiration rates. Several genes related to the drought response were highly expressed in these plants when submitted to a severe water deficit treatment. The results indicated that overexpression of AtDREB1A in soybeans may enhance drought tolerance (Polizel et al., 2011).

The members of the WRKY TF superfamily play a key role in regulating the pathogen-induced defense responses (Dong et al., 2003) and abiotic stress responses (Fowler and Thomashow, 2002; Mare et al., 2004) and are involved in various physiological processes, including senescence, trichome development and secondary metabolite biosynthesis (Eulgem et al., 2000). A previous study on the global gene expression of compatible and incompatible interactions led to the identification of several WRKY TFs that were differentially regulated during infection (Van de Mortel et al., 2007). A total of 64 soybean WRKY TFs were silenced using VIGS to test their involvement in plant resistance (Pandey et al., 2011). The screen resulted in the identification of three WRKY TFs (GmWRKY36, GmWRKY40, and GmWRKY45) that compromised plant resistance when silenced.

From a consumer perspective, the focus on valueadded traits, especially nutrient improvement, is of the greatest interest. McGloughlin (2008) reported examples of transgenic soybean plants with nutritionally improved traits, including modifications of the protein quality and level, essential amino acids, oils and fatty acids, functional secondary metabolites and mineral availabilities. More recently, both oil content and quality have drawn significant attention, and efforts have been made to increase oxidative stability, enhance $\omega-3$ fatty acid content and increase the total oil amount in soybean seeds (Clemente and Cahoon, 2009). Soybean biotech with high oleic acid levels has already been granted regulatory approval for commercialization (CERA, 2010).

Regarding soybean plants as production factories for therapeutic products, Piller et al. (2005) demonstrated the possibility of expressing an immunogenic subunit antigen in soybean as the first step toward the development of a plant edible vaccine for cattle. In addition, the human growth hormone (hGH) and human coagulation factor IX (hFIX) were produced in genetically engineered soybean seeds (Cunha et al., 2010a,b).

Soybean oil represents the most widely available feedstock for biodiesel due to its enhanced biodegradation, increased flashpoint, reduced toxicity, lower emissions and increased lubricity (Kinney and Clemente, 2004). However, because of the high proportion of polyunsaturated fatty acids, soybean oil is oxidatively unstable, and an oxidized biofuel can compromise engine performance (Canakci et al., 1999). To maximize the fuel characteristics of the biodiesel, Duffield et al. (1998) suggested the devel- 
opment of an oil that is high in oleic acid and low in saturated fatty acids. The implementation of biotechnology tools to directly target the perturbation of oil metabolism in soybean has been shown to produce a high-oleic-acid phenotype (Mazur et al., 1999). Buhr et al. (2002) described the development of transgenic soybean events in which the expression of two genes was simultaneously downregulated in seeds, generating soybean oil with reduced palmitic acid and increased oleic acid contents. One of those events was evaluated as a feedstock for biodiesel (Graef et al., 2009). The extruded oil showed improved cold flow and enhanced oxidative stability.

\section{Conclusions}

Since the first studies on transformation, significant advances have been achieved despite soybean recalcitrance to regeneration and transformation. The difficulty of transforming soybeans is evidenced by the few reports on soybean gene expression in a homologous system. New phenotypes obtained by the transgenic approach are useful for functional gene studies and crop improvement. The first generation of commercialized soybean biotechnology products were crops focusing largely on input agronomic traits, such as herbicide tolerance and insect resistance. The present and future focus is on the continuing improvement of agronomic traits, value-added output traits such as improved nutrition and food functionality, and plant factories for therapeutics and industrial products. In the near future, functional studies may indicate new proteins and promoters with biotechnological interest that can be applied to soybean improvement through genetic engineering.

Transgene integration into plant genomes occurs randomly using any of the transformation methodologies currently available for the soybean. Recently, a novel approach was designed to recognize a target sequence in the genome of any eukaryote and direct the insertion of transgenes into this locus. Direct-DNA delivery methods combine high-fidelity DNA recognition/cleavage by engineered zinc-finger nucleases (ZFNs) and homologydirected repair at the specified break sites (a widely conserved biological pathway). This approach enables the targeted mutagenesis of an endogenous gene, targeted gene addition at an endogenous locus and/or targeted genome editing at an endogenous locus (Wright et al., 2005; Shukla et al., 2009). ZFN-mediated transformation has already been reported for some plant species, such as tobacco (Wright et al., 2005; Cai et al., 2008), Arabidopsis (Lloyd et al., 2005) and maize (Shukla et al., 2009). Direct-DNA delivery methods can be extended to the genome modification of any plant species that is amenable to tissue culture and regeneration, including soybean. This approach, combined with rapid advances in genome sequencing technologies and bioinformatics and the increasing efficiency of DNA delivery methods, establishes an efficient and precise strategy for plant genome engineering.

\section{References}

Agarwal PK, Agarwal P, Reddy MK and Sopory SK (2006) Role of DREB transcription factors in abiotic and biotic stress tolerance in plants. Plant Cell Rep 25:1263-1274.

Aragão FJL, Sarokin L, Vianna GR and Rech EL (2000) Selection of transgenic meristematic cells utilizing a herbicidal molecule results in the recovery of fertile transgenic soybean [Glycine $\max (\mathrm{L})$ Merrill] plants at a high frequency. Theor Appl Genet 101:1-6.

Baulcombe DC (1999) Fast forward genetics based on virusinduced gene silencing. Curr Opin Plant Biol 2:109-113.

Boetti H, Chevalier L, Denmat LA, Thomas D and Thomasset B (1999) Efficiency of physical (light) or chemical (ABA, tetracycline, $\mathrm{CuSO}_{4}$ or 2-CBSU) - stimulus-dependent gus gene expression in tobacco cell suspensions. Biotechnol Bioeng 64:1-13.

Brasileiro ACM and Lacorte C (2000) Agrobacterium: Um sistema natural de transferência de genes para plantas. Biotecnol Cienc Desenvolv 15:12-15.

Broothaerts W, Mitchell HJ, Weir B, Kaines S, Smith LMA, Yang W, Mayer JE, Roa-Rodriguez C and Jefferson RA (2005) Gene transfer to plants by diverse species of bacteria. Nature 433:629-633.

Buhr T, Sato S, Ebrahim F, Xing A, Zhou Y, Mathiesen M, Schweiger B, Kinney AJ, Staswick P and Clemente T (2002) Ribozyme termination of RNA transcripts down-regulate seed fatty acid genes in transgenic soybean. Plant J 30:155163.

Burch-Smith TM, Anderson JC, Martin GB and Dinesh-Kumar SP (2004) Applications and advantages of virus-induced gene silencing for gene function studies in plants. Plant $\mathrm{J}$ 39:734-746.

Burton RADMG, Bacic A, Findlay K, Roberts K, Hamilton A, Baulcombe DC and Fincher GB (2000) Virus-induced silencing of a plant cellulose synthase gene. Plant Cell 12:691-705.

Cai CQ, Doyon Y, Ainley WM, Miller JC, DeKelver RC, Moehle EA, Rock JM, Lee YL, Garrison R, Schulenberg L, et al. (2008) Targeted transgene integration in plant cells using designed zinc finger nucleases. Plant Mol Biol 69:699-709.

Canakci M, Monyem A and Van Gerpen J (1999) Accelerated oxidation processes in biodiesel. Trans ASAE 42:1565-1572.

Cao D, Hou W, Song S, Sun H, Wu C, Gao Y and Han T (2009) Assessment of conditions affecting Agrobacterium rhizogenes-mediated transformation of soybean. Plant Cell Tiss Org Cult 96:45-52.

Chen M, Wang QY, Cheng XG, Xu ZS, Li LC, Ye XG, Xia LQ and Ma YZ (2007) GmDREB2, a soybean DRE-binding transcription factor, conferred drought and high-salt tolerance in transgenic plants. Biochem Biophys Res Commun 353:299-305.

Chen M, Xu Z, Xia L, Li L, Cheng X, Dong J, Wang Q and Ma Y (2009) Cold-induced modulation and functional analyses of the DRE-binding transcription factor gene, GmDREB3, in soybean (Glycine max L.). J Exp Bot 60:121-135.

Chiera JM, Bouchard RA, Dorsey SL, Park EH, Buenrostro-Nava MT, Ling PP and Finer JJ (2007) Isolation of two highly active soybean (Glycine $\max$ (L.) Merr.) promoters and their characterization using a new automated image collection and analysis system. Plant Cell Rep 26:1501-1509. 
Cho HJ, Farrand SK and Noel GR (2000) High-efficiency induction of soybean hairy roots and propagation of the soybean cyst nematode. Planta 210:195-204.

Cho MJ, Widholm JM and Vodkin LO (1995) Cassettes for seed-specific expression tested in transformed embryogenic cultures of soybean. Plant Mol Biol Rep 13:255-269.

Christey MC (2001) Use of Ri mediated transformation for production of transgenic plants. In Vitro Cell Dev Biol Plant 37:687-700.

Christianson ML, Warnick DA and Carlson PS (1983) A morphogenetically competent soybean suspension culture. Science 222:632-634.

Christou P and McCabe DE (1992) Prediction of germ-line transformation events in chimeric R0 transgenic soybean plantlets using tissue-specific expression patterns. Plant $\mathbf{J}$ 2:283-290.

Christou P, McCabe DE and Swain WF (1988) Stable transformation of soybean callus by DNA-coated gold particles. Plant Physiol 87:671-674.

Christou P, McCabe DE, Martinell BJ and Swain WF (1990) Soybean genetic engeneering-commercial products of transgenic plants. Trends Biotechnol 18:145-151.

Christou P, Swain WF, Yang NS and McCabe DE (1989) Inheritance and expression of foreign genes in transgenic soybean plants. Genetics 88:7500-7504.

Chung E, Cho CW, Yun BH, Choi HK, So HA, Lee SW and Lee $\mathrm{JH}$ (2009) Molecular cloning and characterization of the soybean DEAD-box RNA helicase gene induced by low temperature and high salinity stress. Gene 443:91-99.

Clemente TE and Cahoon EB (2009) Soybean oil: Genetic approaches for modification of functionality and total content. Plant Physiol 151:1030-1040.

Collier R, Fuchs B, Walter N, Kevin LW and Taylor CG (2005) Ex vitro composite plants: An inexpensive, rapid method for root biology. Plant J 43:449-457.

Cunha NB, Murad AM, Cipriano TM, Araújo ACG, Aragão FJL, Leite A, Vianna GR, McPhee TR, Souza GHMF, Michael J, et al. (2010a) Expression of functional recombinant human growth hormone in transgenic soybean seeds. Transgenic Res 20:811-826.

Cunha NB, Murad AM, Ramos GL, Maranhão AQ, Brígido MM, Araújo ACG, Lacorte C, Aragão FJL, Covas DT, Fontes AM, et al. (2010b) Accumulation of functional recombinant human coagulation factor IX in transgenic soybean seeds. Transgenic Res 20:841-855.

De Ronde JA, Cress WA, Krüger GHJ, Strasser RJ and Van Staden J (2004a) Photosynthetic response of transgenic soybean plants, containing an Arabidopsis P5CR gene during heat and drought stress. J Plant Physiol 161:1211-1224.

De Ronde JA, Laurie RN, Caetano T, Greyling MM and Kerepesi I (2004b) Comparative study between transgenic and nontransgenic soybean lines proved transgenic lines to be more drought tolerant. Euphytica 158:123-132.

DeCleene M and DeLey J (1976) The host range of crown gall. Bot Gaz 42:389-466.

Dhaubhadel S, Farhangkhoee M and Chapman R (2008) Identification and characterization of isofiavonoid specific glycosyltransferase and malonyltransferase from soybean seeds. J Exp Bot 59:981-994.
Dong J, Chen C and Chen Z (2003) Expression profiles of the Arabidopsis WRKY gene superfamily during plant defense response. Plant Mol Biol 51:21-37.

Droste A, Bodanese-Zanettini MH, Mundstock E and Hu CY (1994) Susceptibility of Brazilian soybean cultivars to Agrobacterium tumefaciens. Braz J Genet 17:83-88.

Droste A, Pasquali G and Bodanese-Zanettini MH (2000) Integrated bombardment and Agrobacterium transformation system: An alternative method for soybean transformation. Plant Mol Biol Rep 18:51-59.

Droste A, Pasquali G and Bodanese-Zanettini MH (2002) Transgenic fertile plants of soybean [Glycine $\max (\mathrm{L})$ Merrill] obtained from bombarded embryogenic tissue. Euphytica 127:367-376.

Duffield J, Shapouri H, Graboski M, McCormick R and Wilson R (1998) US Biodiesel Development: New Markets for Conventional and Genetically Modified Agricultural Products. Economic Research Service/United States Department of Agriculture, Washington, DC, $32 \mathrm{pp}$.

Eulgem T, Rushton PJ, Robatzek S and Somssich IE (2000) The WRKY superfamily of plant transcription factors. Trends Plant Sci 5:199-206.

Finer JJ (1988) Apical proliferation of embryogenic tissue of soybean [Glycine $\max (\mathrm{L}$.$) Merrill]. Plant Cell Rep 7:238-241.$

Finer JJ and McMullen MD (1991) Transformation of soybean via particle bombardment of embryogenic suspension culture tissues. In Vitro Cell Dev Biol 27:175-182.

Finer JJ and Nagasawa A (1988) Development of an embryogenic suspension culture of soybean (Glycine max Merrill). Plant Cell Tiss Org Cult 15:125-136.

Finer JJ, Vain P, Jones MW and McMullen MD (1992) Development of the particle inflow gun for DNA delivery to plant cells. Plant Cell Rep 11:323-328.

Fowler S and Thomashow F (2002) Arabidopsis transcriptome profiling indicates that multiple regulatory pathways are activated during cold acclimation in addition to the CBF cold response pathway. Plant Cell 14:1675-1690.

Gelvin SB (2003) Agrobacterium and plant transformation: The biology behind the "gene-jockeying" tool. Microbiol Mol Biol Rev 67:16-37.

Gelvin SB (2010a) Finding a way to the nucleus. Curr Opin Microbiol 13:53-58.

Gelvin SB (2010b) Plant proteins involved in Agrobacterium-mediated genetic transformation. Annu Rev Phytopathol 48:45-68.

Gepts P, Beavis WD, Brummer EC, Shoemaker RC, Stalker HT, Weeden NF and Young ND (2005) Legumes as a model plant family. Genomics for Food and Feed Report of the Cross-Legume Advances through Genomics Conference. Plant Physiol 137:1228-1235.

Govindarajulu M, Kim SY, Libault M, Berg RH, Tanaka K, Stacey G and Taylor CG (2009) GS52 ecto-apyrase plays a critical role during soybean nodulation. Plant Physiol 149:994-1004.

Graef G, LaVallee BJ, Tenopir P, Tat ME, Schweiger BJ, Kinney AJ, Van Gerpen J and Clemente TE (2009) A high oleic acid and low palmitic acid soybean: Agronomic performance and evaluation as a feedstock for biodiesel. Plant Biotechnol J 7:411-421. 
Hadi MZ, McMullen MD and Finer JJ (1996) Transformation of 12 different plasmids into soybean via particle bombardment. Plant Cell Rep 15:500-505.

Hayashi S, Gresshoff PM and Kinkema M (2008) Molecular analysis of lipoxygenases associated with nodule development in soybean. Mol Plant Microbe Interact 21:843-853.

Hernandez-Garcia CM, Bouchard RA, Rushton PJ, Jones ML, Chen X, Timko MP and Finer JJ (2010) High level transgenic expression of soybean (Glycine max) GmERF and Gmubi gene promoters isolated by a novel promoter analysis pipeline. BMC Plant Biol 10:e237.

Hernandez-Garcia CM, Martinelli AP, Bouchard RA and Finer JJ (2009) A soybean (Glycine max) polyubiquitin promoter gives strong constitutive expression in transgenic soybean. Plant Cell Rep 28:837-849.

Hinchee MA, Connor-Ward DV, Newell CA, McDonell RE, Sato SJ, Gasser CS, Fishhoff DA, Re DB, Fraley RT and Horsch RB (1988) Production of transgenic soybean plants using Agrobacterium-mediated DNA transfer. Bio/Technol 6:915-922.

Homrich MS, Passaglia LMP, Pereira JF, Bertagnolli PF, Pasquali G, Zaidi MA, Altosaar I and Bodanese-Zanettini $\mathrm{MH}$ (2008a) Resistance to Anticarsia gemmatalis Hübner (Lepidoptera, Noctuidae) in transgenic soybean (Glycine max (L) Merrill Fabales, Fabaceae) cultivar IAS5 expressing a modified Cry1Ac endotoxin. Genet Mol Biol 31:522-531.

Homrich MS, Passaglia LMP, Pereira JF, Bertagnolli PF, Salvadori JR, Nicolau M, Kaltchuk-Santos E and Bodanese-Zanettini MH (2008b) Agronomic performance, chromosomal stability and resistance to velvetbean caterpillar of transgenic soybean expressing $c r y l A c$ gene. Pesq Agropec Bras 43:801-807.

Hong HP, Zhang H, Olhoft P, Hill S, Wiley H, Toren E, Hillebrand $\mathrm{H}$, Jones $\mathrm{T}$ and Cheng $\mathrm{M}$ (2007) Organogenic callus as the target for plant regeneration and transformation via Agrobacterium in soybean (Glycine max (L) Merr). In Vitro Cell Dev Biol Plant 43:558-568.

Hongyu Z, Ziniu Y and Wangxi D (2000) Composition and ecological distribution of Cry protein and their genotypes of $B a$ cillus thuringiensis isolates from warehouses in China. $\mathrm{J}$ Invertebr Pathol 76:191-197.

Huang F, Chi Y, Gai J and Yu D (2009) Identification of transcription factors predominantly expressed in soybean fiowers and characterization of GmSEP1 encoding a SEPALLATA1like protein. Gene 438:40-48.

Hur YS, Shin KH, Kim S, Nam KH, Lee MS, Chun JY and Cheon CI (2009) Overexpression of GmAKR1, a stress-induced aldo/keto reductase from soybean, retards nodule development. Mol Cell 27:217-223.

James C (2011) Global status of commercialized biotech/GM crops. ISAAA Brief 2011:43 (ISAAA, Ithaca, New York).

Job D (2002) Plant biotechnology in agriculture. Biochimie 84:1105-1110.

Karimi M, Inze D and Depicker A (2002) GATEWAY vectors for Agrobacterium-mediated plant transformation. Trends Plant Sci 7:193-195.

Kereszt A, Li D, Indrasumunar A, Nguyen CD, Nontachaiyapoom S, Kinkema M and Gresshoff PM (2007) Agrobacterium rhizogenes-mediated transformation of soybean to study root biology. Nat Protoc 2:948-952.
Kim JC, Lee SH, Cheong YH, Yoo CM, Lee SI, Chun HJ, Yun DJ, Hong JC, Lee SY, Lim CO, et al. (2001) A novel cold-inducible zinc finger protein from soybean, SCOF-1, enhances cold tolerance in transgenic plants. Plant J 25:247-259.

Kinney AJ and Clemente TE (2004) Modifying soybean oil for enhanced performance in biodiesel blends. Fuel Processing Technol 86:1137-1147.

Ko TS, Lee S, Farrand SK and Korban SS (2004) A partially disarmed vir helper plasmid, pKYRT1, in conjunction with 2,4-dichlorophenoxyacetic acid promotes emergence of regenerable transgenic somatic embryos from immature cotyledons of soybean. Planta 218:536-541.

Ko TS, Lee S, Krasnyanski S and Korban SS (2003) Two critical factors are required for efficient transformation of multiple soybean cultivars: Agrobacterium strain and orientation of immature cotyledonary explant. Theor Appl Genet 107:439-447.

Kocsy G, Laurie R, Szalai G, Szilagyi V, Simon-Sarkadi L, Galiba G and De Ronde JA (2005) Genetic manipulation of proline levels affects antioxidants in soybean subjected to simultaneous drought and heat stresses. Physiol Plant 124:227-235.

Kohli A, Twyman RM, Abranches R, Weget E, Stoger E and Christou P (2003) Transgene integration, organization and interaction in plants. Plant Mol Biol 52:247-258.

Kokkirala VR, Peng Y, Abbagani S, Zhu Z and Umate P (2010) Subcellular localization of proteins of Oryza sativa L. in the model tobacco and tomato plants. Plant Signal Behav 5:1336-1341.

Krajewska B (2009) Ureases I. Functional, catalytic and kinetic properties: A review. J Mol Catalysis B Enzymat 59:9-21.

Larkin PJ and Scowcroft WR (1981) Somaclonal variation - A novel source of variability from cell cultures for plant improvement. Theor Appl Genet 60:197-214.

Lee MY, Shin KH, Kim YK, Suh JY, Gu YY, Kim MR, Hur YS, Son O, Kim JS, Song E, et al. (2005) Induction of thioredoxin is required for nodule development to reduce reactive oxygen species levels in soybean roots. Plant Physiol 139:1881-9.

Levy-Booth DJ, Gulden RH, Campbell RG, Powell JR, Klironomos JN, Pauls KP, Swanton CJ, Trevors JT and Dunfield KE (2009) Roundup Ready ${ }^{\circledR}$ soybean gene concentrations in field soil aggregate size classes. FEMS Microbiol Lett 291:175-179.

Li J, Todd TT and Trick HN (2010) Rapid in planta evaluation of root expressed transgenes in chimeric soybean plants. Plant Cell Rep 29:13-123.

Li X and Dhaubhadel S (2011) Soybean 14-3-3 gene family: Identification and molecular characterization. Planta 233:569582.

Li Z, Xing A, Moon BP, McCardell RP, Mills K and Falco SC (2009) Site-specific integration of transgenes in soybean via recombinase-mediated DNA cassette exchange. Plant Physiol 151:1087-1095.

Liu SJ, Wei ZM and Huang JQ (2008) The effect of co-cultivation and selection parameters on Agrobacterium-mediated transformation of Chinese soybean varieties. Plant Cell Rep 27:489-498.

Lloyd A, Plaisier CL, Carroll D and Drews GN (2005) Targeted mutagenesis using zinc-finger nucleases in Arabidopsis. Proc Natl Acad Sci USA 102:2232-2237. 
Lozovaya VV, Lygin AV, Zernova OV, Li S, Hartman GL and Widholm, JM (2004) Isoflavonoid accumulation in soybean hairy roots upon treatment with Fusarium solani. Plant Physiol Biochem 42:671-679.

Lundry DR, Ridley WP, Meyer JJ, Riordan SG, Nemeth MA, Trujillo WA, Breeze ML and Sorbet R (2008) Composition of grain, forage, and processed fractions from second-generation Glyphosate-tolerant soybean, MON 89788, is equivalent to that of conventional soybean (Glycine $\max \mathrm{L}$.). J Agric Food Chem 56:4611-4622.

Ma JK, Drake PM and Christou P (2003) The production of recombinant pharmaceutical proteins in plants. Nat Rev Genet 4:794-805.

Macrae TC, Baur ME, Boethel DJ, Fitzpatrick BJ, Gao AG, Gamundi JC, Harrison LA, Kabuye VT, McPherson RM, Miklos JA, et al. (2005) Laboratory and field evaluations of transgenic soybean exhibiting high-dose expression of a synthetic Bacillus thuringiensis cry1A gene for control of Lepidoptera. J Econ Entomol 98:577-587.

Manavalan LP, Guttikonda SK, Tran LSP and Nguyen HT (2009) Physiological and molecular approaches to improve drought resistance in soybean. Plant Cell Physiol 50:1260-1276.

Mare C, Mazzucotelli E, Crosatti C, Francia E, Stanca AM and Cativelli L (2004) Hv-WRKY38: A new transcription factor involved in cold- and drought-response in barley. Plant Mol Biol 55:399-416.

Mathieu M, Winters EK, Kong F, Wan J, Wang S, Eckert H, Luth D, Paz M, Donovan C, Zhang Z, et al. (2009) Establishment of a soybean (Glycine max Merr. L) transposon-based mutagenesis repository. Planta 229:279-289.

Mauro AOO, Pfeiffer TW and Collins GB (1995) Inheritance of soybean susceptibility to Agrobacterium tumefaciens and its relationship to transformation. Crop Sci 35:1152-1156.

Mazarei M, Elling AA, Maier TR, Puthoff DP and Baum TJ (2007) GmEREBP1 is a transcription factor activating defense genes in soybean and Arabidopsis. Mol Plant Microbe Interact 20:107-119.

Mazur B, Krebbers E and Tingey S (1999) Gene discovery and product development for grain quality traits. Science 285:372-375.

McCabe DE, Swain WF, Martinell BJ and Christou P (1988) Stable transformation of soybean (Glycine max) by particle acceleration. Bio/Technol 6:923-926.

McGloughlin MN (2008) Nutritionally Improved Agricultural Crops. Plant Physiol 147:939-953.

McPherson RM and MacRae TC (2009) Evaluation of transgenic soybean exhibiting high expression of a synthetic Bacillus thuringiensis crylA transgene for suppressing lepidopteran population densities and crop injury. J Econ Entomol 102:1640-1648.

Miklos JA, Alibhai MF, Bledig SA, Connor-Ward DC, Gao AG, Holmes BA, Kolacz KH, Kabuye VT, MacRae TC, Paradise MS, et al. (2007) Characterization of soybean exhibiting high expression of a synthetic Bacillus thuringiensis crylA transgene that confers a high degree of resistance to Lepidopteran pests. Crop Sci 47:148-157.

Nakagawa T, Kurose T, Hino T, Tanaka K, Kawamukai M, Niwa Y, Toyooka K, Matsuoka K, Jinbo T and Kimura T (2007) Development of series of Gateway binary vectors, pGWBs for realizing efficient construction of fusion genes for plant transformation. J Biosci Bioeng 104:34-41.
Nunes AC, Vianna GR, Cuneo F, Amaya-Farfán J, de Capdeville G, Rech EL and Aragão FJ (2006) RNAi-mediated silencing of the myo-inositol-1-phosphate synthase gene (GmMIPS1) in transgenic soybean inhibited seed development and reduced phytate content. Planta 224:125-32.

Odell JT, Nagy F and Chua NH (1985) Identification of DNA sequences required for activity of the cauliflower mosaic virus 35S promoter. Nature 313:810-812.

Olhoft PM, Bernal LM, Grist LB and Ozias-Akins P (2007) A novel Agrobacterium rhizogenes-mediated transformation method of soybean [Glycine max (L.) Merrill] using primary-node explants from seedlings. In Vitro Cell Dev Biol Plant 43:536-549.

Olhoft PM, Flagel LE, Donovan CM and Somers DA (2003) Efficient soybean transformation using hygromycin $\mathrm{B}$ selection in the cotyledonary-node method. Planta 216:723-735.

Padgette SR, Kolacz KH and Delannay X (1995) Development, identification, and characterization of a glyphosate-tolerant soybean line. Crop Sci 35:1451-1461.

Pandey AK, Yang C, Zhang C, Graham MA, Horstman HD, Lee Y, Zabotina OA, Hill JH, Pedley KF and Whitham SA (2011) Functional analysis of the Asian Soybean Rust Resistance Pathway mediated by Rpp2. Mol Plant Microbe Interact 24:194-206.

Parrott WA, All JN, Adang MJ, Bailey MA, Boerma HR and Stewart CN (1994) Recovery and evaluation of soybean (Glycine max [L.] Merr.) plants transgenic for a Bacillus thuringiensis var. Kurstaki insecticidal gene. In Vitro Cell Dev Biol Plant 30:144-149.

Parrott WA, Dryden G, Vogt S, Hildebrand DF, Collins GB and Williams EG (1988) Optimization of somatic embryogenesis and embryo germination in soybean. In Vitro Cell Dev Biol 24:817-820.

Parrott WA, Hoffman LM, Hildebrand DF, Williams EG and Collins GB (1989) Recovery of primary transformants of soybean. Plant Cell Rep 7:615-617.

Paz MM, Martinez JC, Kalvig AB, Fonger TM and Wang K (2006) Improved cotyledonary node method using an alternative explant derived from mature seed for efficient Agrobacterium-mediated soybean transformation. Plant Cell Rep 25:206-213.

Paz MM, Shou H, Guo Z, Zhang Z, Banergee AK and Wang K (2004) Assessment of conditions affecting Agrobacteriummediated soybean transformation using the cotyledonary node explants. Euphytica 136:167-179.

Pedersen HC, Christiansen J and Wyndaele R (1983) Induction and in vitro culture of soybean crown gall tumors. Plant Cell Rep 2:201-204.

Peferöen M (1997) Progress and prospects for field use of $B t$ genes in crops. Trends Biotechnol 15:173-177.

Piller JK, Clemente TE, Jun SM, Petty CC, Sato S, Pascual DW and Bost KL (2005) Expression and immunogenicity of an Escherichia coli K99 fimbriae subunit antigen in soybean. Planta 222:6-18.

Pitzschke A and Hirt H (2010) New insights into an old story: Agrobacterium-induced tumour formation in plants by plant transformation. EMBO J 29:1021-1032.

Polizel AM, Medri ME, Nakashima K, Yamanaka N, Farias JRB, Oliveira MCN, Marin SRR, Abdelnoor RV, Marcelino-Guimarães FC, Fuganti R, et al. (2011) Molecular, anatomical and physiological properties of a genetically modified soy- 
bean line transformed with rd29A:AtDREB1A for the improvement of drought tolerance. Genet Mol Res 10:36413656.

Preiszner J, Van Toait T, Huynh L, Bolla RI and Yen HH (2001) Structure and activity of a soybean Adh promoter in transgenic hairy roots. Plant Cell Rep 20:763-769.

Qinggele C, Mingchun L, Dongsheng W, Yi C and Laijun X (2007) Isolation and sequencing analysis on the seed-specific promoter from soybean. Frontiers of Agriculture in China 1:17-23.

Rao SS, Mamadou L, McConnell M, Polisetty R, Kwanyuen P and Hildebrand D (2009) Non-antibiotic selection systems for soybean somatic embryos: The lysine analog aminoethyl-cysteine as a selection agent. BMC Biotechnology 9:e94.

Rech EL, Vianna GR and Aragão FJL (2008) High-efficiency transformation by biolistics of soybean, common bean and cotton transgenic plants. Nat Protoc 3:410-418.

Sanford JC (1988) The biolistic process. Trends Biotechnol 6:299-302.

Sanford JC (1990) Biolistic plant transformation. Plant Physiol 79:206-209.

Sathasivan K, Haughn GW and Murai N (1991) Molecular basis of Imidazolinone herbicide resistance in Arabidopsis thaliana var Columbia. Plant Physiol 97:1044-1050.

Sato S, Newell C, Kolacz K, Tredo L, Finer JJ and Hinchee M (1993) Stable transformation via particle bombardment in two different soybean regeneration systems. Plant Cell Rep 12:408-413.

Schmutz J, Cannon SB, Schlueter J, Ma J, Mitros T, Nelson W, Hyten DL, Song Q, Thelen JJ and Cheng J (2010) Genome sequence of the palaeopolyploid soybean. Nature 463:178183.

Shukla VK, Doyon Y, Miller JC, DeKelver RC, Moehle EA, Worden SE, Mitchell JC, Arnold NL, Gopalan S, Meng X, et al. (2009) Precise genome modification in the crop species Zea mays using zinc-finger nucleases. Nature 459:437-441.

Singh RJ, Klein TM, Mauvais CJ, Knowlton S, Himowitz T and Kostow CM (1998) Cytological characterization of transgenic soybean. Theor Appl Genet 96:319-324.

Somers DA, Samac DA and Olhoft PM (2003) Recent advances in legume transformation. Plant Physiol 131:892-899.

Stewart Jr CN, Adang MJ, All JN, Boerma HR, Cardineau G, Tucker D and Parrott WA (1996) Genetic transformation, recovery, and characterization of soybean (Glycine max [L.] Merrill) transgenic for a synthetic Bacillus thuringiensis CRYIA(c) gene. Plant Physiol 112:121-129.

Subramanian S, Graham MY, Yu O and Graham TL (2005) RNA interference of soybean isoflavone synthase genes leads to silencing in tissues distal to the transformation site and to enhanced susceptibility to Phytophthora sojae. Plant Physiol 137:1-9.

Subramanian S, Hu X, Lu G, Odelland JT and Yu O (2004) The promoters of two isoflavone synthase genes respond differentially to nodulation and defense signals in transgenic soybean roots. Plant Mol Biol 54:623-639.

Sussex IM (1989) Developmental programming of the shoot meristem. Cell 56:225-229.

Tadege M, Ratet P and Mysore KS (2005) Insertional mutagenesis: A swiss army knife for functional genomics of Medicago truncatula. Trends Plant Sci 10:229-235.
Tran LSP and Mochida K (2010) Functional genomics of soybean for improvement of productivity in adverse conditions. Funct Integr Genomics 10:447-462.

Trick HN and Finer JJ (1998) Sonication-assisted Agrobacterium-mediated transformation of soybean (Glycine max) embryogenic suspension culture tissue. Plant Cell Rep 17:482-488.

Trick HN, Dinkins RD, Santarém ER, Di R, Samoylov V, Meurer CA, Walker DR, Parrott WA, Finer JJ and Collins GB (1997a) Recent advances in soybean transformation. Plant Tiss Cult Biotechnol 3:9-24.

Trick HN, Dinkins RD, Santarém ER, Di R, Samoylov V, Meurer CA, Walker DR, Parrott Trick HN and Finer JJ (1997b) SAAT: Aonication-assisted Agrobacterium-mediated transformation. Transgenic Res 6:329-336.

Van de Mortel M, Recknor JC, Graham MA, Nettleton D, Dittman JD, Nelson RT, Godoy CV, Abdelnoor RV, Almeida AMR, Baum TJ, et al. (2007) Distinct biphasic mRNA changes in response to Asian soybean rust infection. Mol Plant Microbe Interact 20:887-899.

Vianna GR, Aragão FJL and Rech EL (2011) A minimal DNA cassette as a vector for genetic transformation of soybean (Glycine max). Genet Mol Res 10:382-390.

Walker DR, All JN, McPherson RM, Boerma HR and Parrott WA (2000) Field evaluation of soybean engineered with a synthetic cry1 Ac transgene for resistance to corn earworm, soybean looper, velvetbean caterpillar (Lepidoptera, Noctuidae), and lesser cornstalk borer (Lepidoptera, Pyralidae). J Econ Entomol 93:613-622.

Wang G and Xu Y (2008) Hypocotyl-based Agrobacterium-mediated transformation of soybean (Glycine max) and application for RNA interference. Plant Cell Rep 27:1177-1184.

Weigel D, Ahn JH, Blazquez MA, Borewitz J, Christensen SK, Fankhauser C, Ferrandiz C, Kardailsky I, Malanchaurvil EJ, Ne MM, et al. (2000) Activation tagging in Arabidopsis. Plant Physiol 122:1003-1013.

Wesley VS Helliwell CA, Smith NA, Wang MB, Rouse DT, Liu Q, Gooding PSSPS, Abbott D, Stoutjesdijk PA, Robinson SP, et al. (2001) Construct design for efficient, effective and high-throughput gene silencing in plants. Plant J 27:581590 .

Wiebke B, Ferreira F, Pasquali G, Bodanese-Zanettini MH and Droste A (2006) Influence of antibiotics on embryogenic tissue and Agrobacterium tumefaciens suppression in soybean genetic transformation. Bragantia 65:543-551.

Wiebke-Strohm B, Droste A, Pasquali G, Osorio MB, BückerNeto L, Passaglia LMP, Bencke M, Homrich MS, MarM and Bodanese-Zanettini MH (2011) Transgenic fertile soybean plants derived from somatic embryos transformed via the combined DNA-free particle bombardment and Agrobacterium system. Euphytica 177:343-354.

Wiebke-Strohm B, Pasquali G, Margis-Pinheiro M, Bencke M, Bücker-Neto M, Becker-Ritt AB, Martinelli AHS, Polacco JC, Stolf R, Marcelino FC, et al. (2012) Ubiquitous urease affects soybean susceptibility to fungi. Plant Mol Biol 79:75-87.

Williams ES and Maheswaran B (1986) Somatic embryogenesis: Factors influencing coordinated behavior of cells as an embryogenic group. Ann Bot 57:443-462.

Wright, DA, Townsend JA, Winfrey Jr JJ, Irwin PA, Rajagopal J, Lonosky PM, Hall BD, Jondle MD and Voytas DF (2005) 
High-frequency homologous recombination in plants mediated by zinc-finger nucleases. Plant J 44:693-705.

Wu C, Chiera JM, Ling PP and Finer JJ (2008) Isoxaflutole treatment leads to reversible tissue bleaching and allows for more effective detection of GFP in transgenic soybean tissues. In Vitro Cell Dev Biol Plant 44:540-547.

Xing A, Moon BP, Mills KM, Falco SC and Li Z (2010) Revealing frequent alternative polyadenylation and widespread low-level transcription read-through of novel plant transcription terminators. Plant Biotechnol J 8:772-782.

Xue R and Zhang B (2007) Increased endogenous methyl jasmonate altered leaf and root development in transgenic soybean plants. J Genet Genomics 34:339-346.

Yan B, Reddy MSS, Collins GB and Dinkins RD (2000) Agrobacterium tumefaciens mediated transformation of soybean [Glycine $\max (\mathrm{L})$ Merrill] using immature zygotic cotyledon explants. Plant Cell Rep 19:1090-1.

Yang L, Ji W, Zhu Y, Gao P, Li Y, Cai H, Bai X and Guo D (2010) GsCBRLK, a calcium/calmodulin-binding receptor-like kinase, is a positive regulator of plant tolerance to salt and ABA stress. J Exp Bot 61:2519-2533.

Yanxiang S, Dan W, Yanling B, Ningning W and Yong W (2006) Studies on the overexpression of the soybean GmNHX1 in Lotus corniculatus: The reduced $\mathrm{Na}+$ level is the basis of the increased salt tolerance. Chin Sci Bull 51:1306-1315.

Yi J, Derynck MR, Li X, Telmer P, Marsolais F and Dhaubhadel S (2010) A single-repeat MYB transcription factor, GmMYB176, regulates CHS8 gene expression and affects isofiavonoid biosynthesis in soybean. Plant J 62:1019-1034.

Zeng P, Vadnais DA, Zhang Z and Polacco JC (2004) Refined glufosinate selection in Agrobacterium-mediated transformation of soybean [Glycine $\max (\mathrm{L}$.) Merrill]. Plant Cell Rep 22:478-482.

Zhang C, Yang C, Whitham SA and Hill JH (2009a) Development and use of an efficient DNA-based viral gene silencing vector for soybean. Mol Plant Microbe Interact 22:123-131.

Zhang G, Chen M, Li L, Xu Z, Chen X, Guo J and Ma Y (2009b) Overexpression of the soybean GmERF3 gene, an AP2/ERF type transcription factor for increased tolerances to salt, drought, and diseases in transgenic tobacco. J Exp Bot 60:3781-3796.

Zhang J (2003) Overexpression analysis of plant transcription factors. Curr Opin Plant Biol 6:430-440.

Zhang Z, Xing A, Staswick PE and Clemente TE (1999) The use of glufosinate as a selective agent in Agrobacteriummediated transformation of soybean. Plant Cell Tissue Organ Cult 56:37-46.

Zhou GA, Chang RZ and Qiu LJ (2010) Overexpression of soybean ubiquitin-conjugating enzyme gene GmUBC2 confers enhanced drought and salt tolerance through modulating abiotic stress-responsive gene expression in Arabidopsis. Plant Mol Biol 72:357-367.

\section{Internet Resources}

Celeres, http://www.celeres.com.br (July 10, 2012).

National Technical Commission on Biosecurity in Brazil, http//:www.ctnbio.gov.br.

Center for Environmental Risk Assessment (CERA), http://cera-gmc.org/ (March 10, 2012).

CERA (2010) GM Crop Database. Center for Environmental Risk Assessment (CERA), ILSI Research Foundation, Washington D.C. http://cera-gmc.org/index.php?action=gm_crop_database (March 15, 2012).

Chabaud M, Boisson-Dernier A, Zhang J, Taylor CG, Yu O and Barker DG (2006) Agrobacterium rhizogenes-mediated root transformation. In: Mathesius U, Journet EP and Sumner LW (eds) Medicago truncatula Handbook. $1^{\text {st }}$ edition. Vol 1. Samuel Roberts Noble Foundation, http://www.noble.org/MedicagoHandbook (July 10, 2012).

License information: This is an open-access article distributed under the terms of the Creative Commons Attribution License, which permits unrestricted use, distribution, and reproduction in any medium, provided the original work is properly cited. 